\title{
AGELENIN, A SPIDER NEUROTOXIN: DETERMINATION OF THE C-TERMINUS AS AMIDE FORM, AND INVESTIGATION OF THE DISULFIDE BOND ARRANGEMENT
}

\author{
Ken'ichi Hagiwara ${ }^{1}$, Tatsuya Inui ${ }^{2}$, Kiichiro Nakajima ${ }^{2}$, Terutoshi Kimura ${ }^{2}$, Chieko Kitada ${ }^{3}$, \\ Masahiko Fujino ${ }^{3}$, Shumpei SaKakibara ${ }^{2}$ and Terumi NaKajima ${ }^{1}$ \\ ${ }^{1}$ Department of Analytical Chemistry, Faculty of Pharmaceutical Sciences, University of Tokyo, Bunkyoku, Tokyo $113,{ }^{2}$ Peptide \\ Institute Inc., Protein Research Foundation, Minohshi, Osaka 562, and ${ }^{3}$ Tsukuba Research Laboratories, Takeda Chemical Indus- \\ tries Ltd., Tsukubashi, Ibaraki 300-42, Japan
}

\begin{abstract}
Agelenin is a neurotoxic peptide previously isolated from the venom of a spider, Agelena opulenta, and consists of 35 amino acid residues. In the present study, the carboxyl terminus of agelenin was found to be amide form but not carboxylic acid form by dansyl-Edman degradation-analysis as well as by peptide synthesis. Among six cysteine (Cys) residues in agelenin, formation of disulfide bond between $\mathrm{Cys}^{10}$ and $\mathrm{Cys}^{24}$ was determined. As for the rest of Cys residues, two possible arrangements of disulfide bonds were $\mathrm{Cys}^{3}-\mathrm{Cys}^{18}$ and $\mathrm{Cys}^{19}{ }^{19} \mathrm{Cys}^{34}$, or $\mathrm{Cys}^{3}-\mathrm{Cys}^{19}$ and $\mathrm{Cys}^{18}-\mathrm{Cys}^{34}$.
\end{abstract}

Spiders have venoms to paralyze or kill insects. During recent years, the venoms of several spiders have been recognized as neurotoxins, and are expected to serve as useful probes in the field of neuroscience (7). To date, spider neurotoxins seem to be chemically classified into two groups. The first is a group of polyamine-like toxins which potently block neuromuscular transmission mediated by glutamic acid, acting on postsynaptic glutamate receptor (8). The second is a group of cysteine (Cys)-rich neuroactive peptides isolated from Atrax robustus (12), Atrax versutus (2), Agelenopsis aperta (13), Eurypelma californicum (11), Agelena opulenta (6), Hololena curta (14) and Phoneutria nigriventer (4).

Agelenin isolated from the venom of Agelena opulenta (6), belongs to the second group. Agelenin is known to suppress excitatory postsynaptic potentials in the lobster neuromuscular junction, possibly by blocking the presynaptic calcium channel. The amino acid sequence of agelenin, consisting of 35 amino acid residues, was previously determined and its carboxyl terminal (C-terminal) residue was reported to be leucine (Leu) by using carboxypeptidase (CP) method (6). However, the method using
$\mathrm{CP}$ hardly revealed whether $\mathrm{Leu}^{35}$ at the C-terminus was carboxylic acid free (Leu-OH) form or amide (Leu- $\mathrm{NH}_{2}$ ) form. In the present study, we determined the C-terminus of agelenin to be Leu$\mathrm{NH}_{2}$ form, by analytical as well as peptide synthesis approach. In addition, we investigated the arrangements of the disulfide bonds in agelenin which has six Cys residues in its amino acid sequence.

\section{MATERIALS AND METHODS}

\section{Materials}

Spiders (Agelena opulenta) were collected in the field in Tokyo. Natural agelenin was purified from the spider according to the method previously described (6). Dansyl chloride (DNS-Cl) was from Kanto Chemical. DNS-L-Leu-OH and DNS-L-cysteic acid (Cys $\mathrm{SO}_{3}{ }^{-}$) were from Sigma. DNS-L-Leu$\mathrm{NH}_{2}$ was prepared from DNS-Cl and L-Leu-NH (Peptide Institute, Osaka, Japan). Trypsin (EC 3.4.21.4) was from Worthington and thermolysin (EC 3.4.24.4) was from Seikagaku Kogyo. Dowex 50 X-8 was obtained from Muromachi Kagaku Kogyo. Chemical synthesis of peptides was performed by the solid phase method. 


\section{Oxidation and Digestion of Agelenin}

Purified agelenin ( $1.5 \mathrm{nmol})$ was oxidized with performic acid to cleave disulfide bonds by the method described elsewhere (16). The oxidized agelenin was digested with trypsin (about $1 \mu \mathrm{g}$ ) in $50 \mu \mathrm{l}$ of $25 \mathrm{mM}$ Tris- $\mathrm{HCl}$ buffer $(\mathrm{pH} 8.0)$ at $40^{\circ} \mathrm{C}$ for $4 \mathrm{~h}$.

\section{Dower 50 Chromatography}

Diluted $\mathrm{HCl}$ solution was added to the tryptic digest of the oxidized agelenin to adjust $\mathrm{pH}$ to about 3 , and the digest was applied onto a Dowex 50 X-8 column $(250 \mu 1$ of resin) equilibrated with $2.5 \mathrm{mM}$ $\mathrm{HCl} / 2$-propanol(2-PrOH) $(80 / 20, \mathrm{v} / \mathrm{v})$. The column was washed with $2.5 \mathrm{ml}$ of $2.5 \mathrm{mM} \mathrm{HCl} / 2-\mathrm{PrOH}$ $(80 / 20, \mathrm{v} / \mathrm{v})$ (fraction I), and eluted with $2.5 \mathrm{ml}$ of $2 \mathrm{M}$ pyridine (fraction II).

\section{Dansyl-Edman Degradation Analysis}

The fraction from the Dowex column containing the C-terminal peptide fragment; $\mathrm{CysSO}_{3}{ }^{-34}-\mathrm{Leu}^{35}$ was dissolved in $100 \mu \mathrm{l}$ of $50 \%$ pyridine aqueous solution. The sample was allowed to react with $5 \mu 1$ of phenylisothiocyanate at $55^{\circ} \mathrm{C}$ for 30 min under nitrogen gas and the excess reagent was discarded by three extractions with $200 \mu$ l of heptane/ethyl acetate $(10 / 1, v / v)$, then three extractions with $200 \mu \mathrm{l}$ of heptane/ethyl acetate $(2 / 1, \mathrm{v} / \mathrm{v})$. After the sample was evaporated to dryness, $30 \mu 1$ of trifluoroacetic acid (TFA) was added and heated at $55^{\circ} \mathrm{C}$ for 5 min under nitrogen gas. To the dried sample, $30 \mu 1$ of water and benzene were added, shaken vigorously and the organic phase was discarded.

The aqueous phase containing C-terminal residue was dried and dissolved in $50 \mu \mathrm{l}$ of $0.5 \mathrm{M}$ $\mathrm{NaHCO}_{3}$. DNS-Cl solution (6 $\mathrm{mg} / \mathrm{ml}$ of acetone) was added and dansylation was proceeded at room temperature overnight. The dansylated sample was analyzed by reversed-phase high performance liquid chromatography (HPLC) using an ODS column (ODS- $80_{\mathrm{TM}}, 4.6 \times 250 \mathrm{~mm}$, Tosoh). The eluent system used was $10 \mathrm{mM}$ sodium acetate buffer $(\mathrm{pH} \mathrm{6.8)/acetonitrile}(95 / 5, \mathrm{v} / \mathrm{v})(\mathrm{A})$ and $10 \mathrm{mM}$ sodium acetate buffer ( $\mathrm{pH}$ 6.8)/acetonitrile (30/70, $\mathrm{v} / \mathrm{v})(\mathrm{B})$. The column was eluted with a linear gradient from $A$ to $B$ in $70 \mathrm{~min}$ at a flow rate of $1.0 \mathrm{ml} /$ min. The column temperature was at $50^{\circ} \mathrm{C}$. DNSderivatives were detected by fluorescence (excitation at $350 \mathrm{~nm}$ and emission at $530 \mathrm{~nm}$ ).

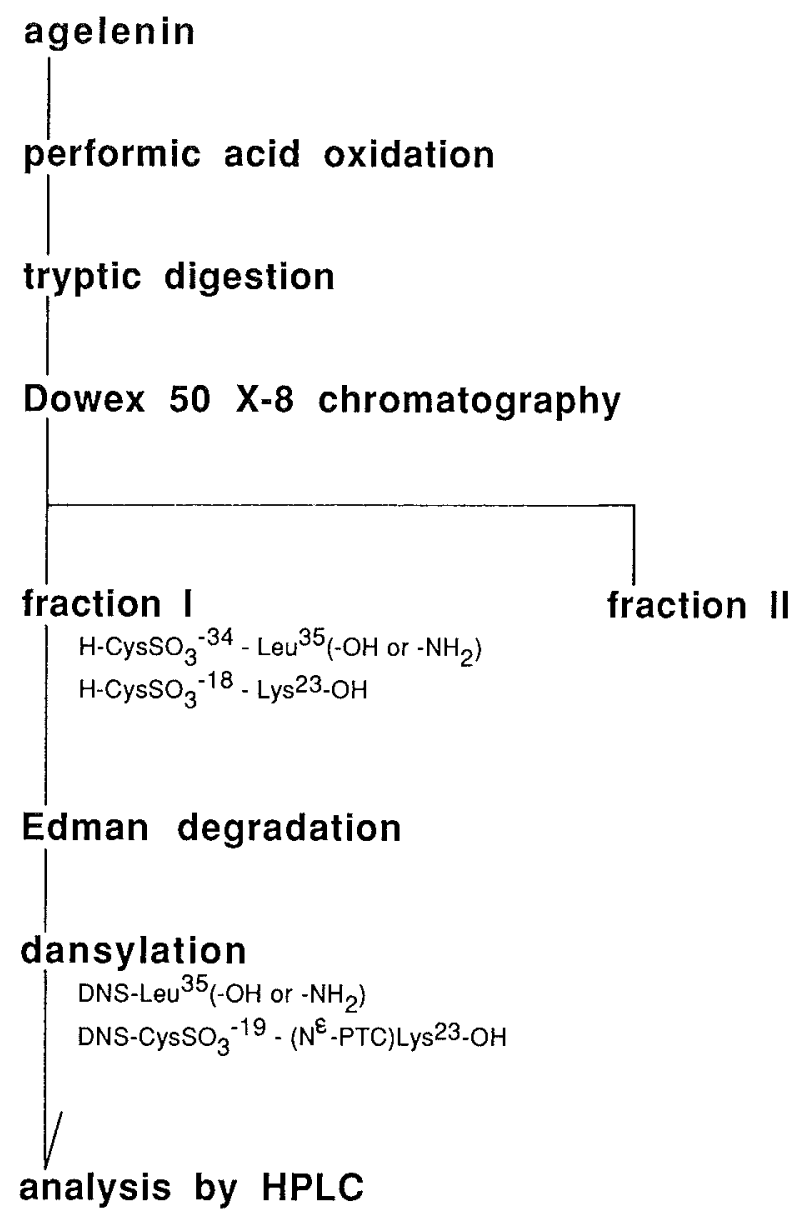

Fig. 1 The strategy for the C-terminus analysis

\section{Comparison of Elution Profiles between Agelenin and Synthetic Peptides}

Two types of peptides having the same amino acid sequence as agelenin except the C-terminal residue, i.e. Leu-OH (Syn-agel-OH) or Leu-NH $\mathrm{NH}_{2}$ (Synagel- $\mathrm{NH}_{2}$ ), were chemically synthesized. The elution profile of agelenin, Syn-agel-OH and Syn-agel$\mathrm{NH}_{2}$ on an ODS column (Inertsil ODS-2, $4.6 \times 250 \mathrm{~mm}$, GL Science) were compared. The column was eluted with water/acetonitrile $(83 / 17$, $\mathrm{v} / \mathrm{v}$ ) containing $0.05 \% \mathrm{TFA}$ at a flow rate of $1.0 \mathrm{ml}$ / min. The column temperature was at $40^{\circ} \mathrm{C}$. Detection was performed by UV absorption at $215 \mathrm{~nm}$. Chromatogram was recorded by an integrator 807 IT (Jasco, Tokyo, Japan). 


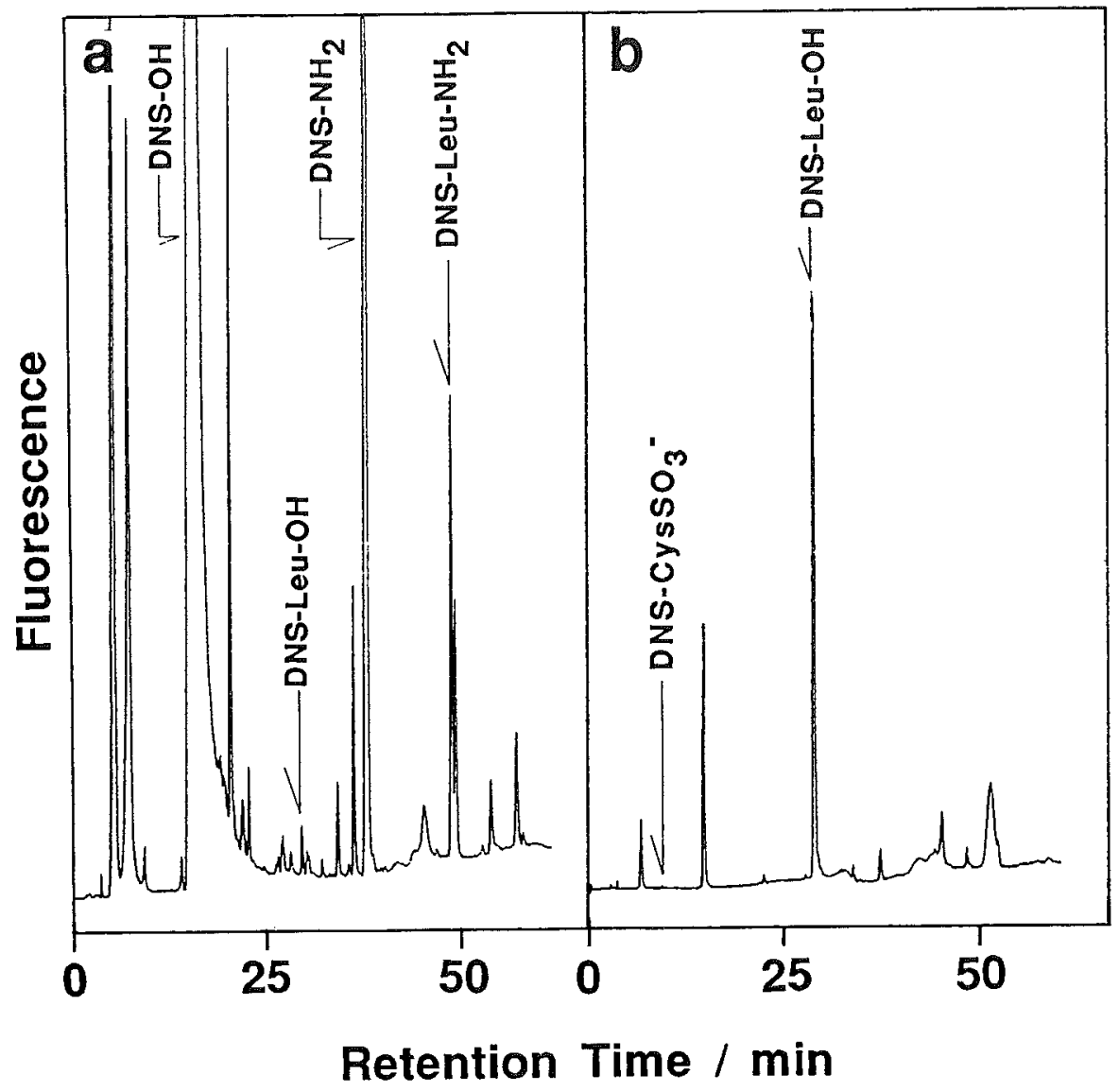

Fig. 2 The C-terminus analysis by dansyl-Edman degradation. The elution positions of authentic dansyl derivatives (DNS-OH, DNS-NH ${ }_{2}$, DNS-Leu-OH, DNSLeu- $\mathrm{NH}_{2}$ and $\mathrm{DNS}-\mathrm{CySSO}_{3}{ }^{-}$) are indicated by arrows. a, the dansylated sample; b, acid hydrolyzate of the peak fraction identified as DNS-Leu- $\mathrm{NH}_{2}$ in (a)

\section{Analysis of Disulfide Bonds}

Agelenin $(2 \mathrm{nmol})$ was dissolved in $20 \mu 1$ of $8 \mathrm{M}$ urea, and then $80 \mu 1$ of $25 \mathrm{mM}$ Tris- $\mathrm{HCl}$ buffer $(\mathrm{pH} 8.0) / 5 \mathrm{mM} \mathrm{CaCl}_{2}$ was added to reduce urea concentration to $1.6 \mathrm{M}$. Then, agelenin was digested with trypsin $(1 \mu \mathrm{g})$ or thermolysin $(1 \mu \mathrm{g})$ at $40^{\circ} \mathrm{C}$ for $12 \mathrm{~h}$. The digest was applied onto the Inertsil ODS-2 column to isolate the peptide fragments. The eluents used were water/acetonitrile $(95 / 5, \mathrm{v} /$ v) (C) and water/acetonitrile (40/60, v/v) (D), both of which contained $0.05 \%$ TFA. Gradient elution from $\mathrm{C}$ to $\mathrm{D}$ in $80 \mathrm{~min}$ was performed at a flow rate of $1.0 \mathrm{ml} / \mathrm{min}$. The column was maintained at $40^{\circ} \mathrm{C}$. Detection was by UV absorption at $215 \mathrm{~nm}$. The purified peptide fragments were subjected to amino acid composition analysis by ion-exchange chromatography using o-phtalaldehyde method
(3), and sequence analysis by the Edman degradation method (15). For microsequencing, an automatic protein sequencer (Type 477A, Applied Biosystems) was used.

\section{RESULTS}

Fig. 1 summarizes the strategy for the C-terminus analysis. When the tryptic digest of the performic acid oxidized agelenin was applied onto the Dowex 50 column, acidic peptide fragments were expected to be recovered in fraction I and neutral fragments in fraction II. Actually, amino acid sequence analysis suggested that the fraction I was a mixture of $\mathrm{CysSO}_{3}{ }^{-34}-\mathrm{Leu}^{35}$ (-OH or $-\mathrm{NH}_{2}$ form; the C-terminal dipeptide fragment) and $\mathrm{CySSO}_{3}{ }^{-18}-\mathrm{Lys}^{23}$, whereas the fraction II was of $\mathrm{Gly}^{1}-\mathrm{Arg}^{8}$, $\mathrm{Phe}^{9}$ $\mathrm{Arg}^{17}, \mathrm{CysSO}_{3}{ }^{-24}-\mathrm{Lys}^{25}$ and $\mathrm{Glu}^{26}-\mathrm{Arg}^{33}$ (data not 


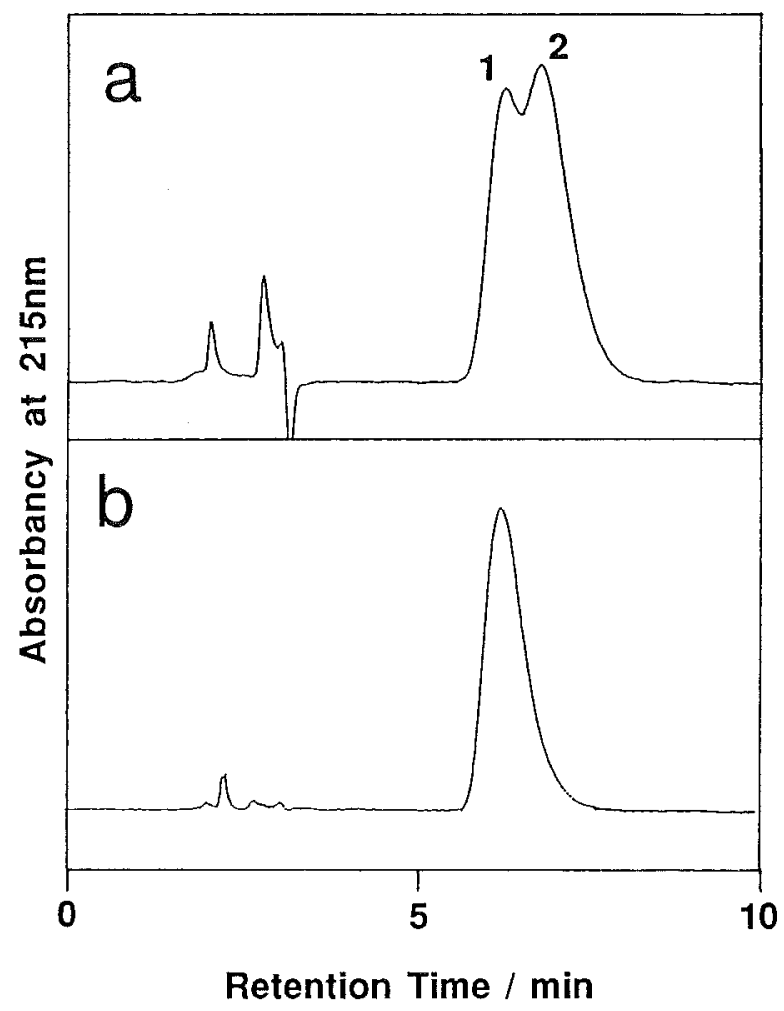

Fig. 3 Elution profiles of agelenin, Syn-agel-OH and Syn-agel- $\mathrm{NH}_{2}$. a, Syn-agel- $\mathrm{NH}_{2}$ (peak 1) and Syn-agel$\mathrm{OH}$ (peak 2) were eluted at $6.4 \mathrm{~min}$ and $6.9 \mathrm{~min}$, respectively; b, agelenin was eluted at $6.4 \mathrm{~min}$.

shown). Thus, the fraction I contained the C-terminal peptide and was therefore subjected to dansyl-Edman degradation analysis. The dansylated sample gave a peak corresponding to the authentic DNS-Leu-NH $\mathrm{N}_{2}$ but not DNS-Leu-OH by HPLC as shown in Fig. 2a. When this peak fraction corresponding to DNS-Leu-NH $\mathrm{N}_{2}$ in Fig. 2 a was collected, hydrolyzed with $5.7 \mathrm{~N} \mathrm{HCl}$ for $5 \mathrm{~h}$ and subjected to rechromatography, a new peak corresponding to the authentic DNS-Leu-OH appeared due to amide bond hydrolysis from Leu-NH $\mathrm{N}_{2}$ to Leu-OH (Fig. 2b; sulfone-amide bond is almost stable under this hydrolysis condition). The peak in Fig. 2a was thus determined to be DNS-Leu-NH${ }_{2}$, and therefore the $\mathrm{C}$-terminal of agelenin was decided to be Leu- $\mathrm{NH}_{2}$ but not Leu-OH.

To support the result of the dansyl-Edman analysis, we compared elution profiles of agelenin and two synthetic peptides; Syn-agel-OH and Syn-agel$\mathrm{NH}_{2}$, on the reversed-phase HPLC. The retention time $\left(t_{R}\right)$ of agelenin $\left(t_{R}=6.4 \mathrm{~min}\right)$ completely coin-
Table 1 Amino Acid Composition of Cys-containing Peptides

\begin{tabular}{lrrrr}
\hline & T-1 & TH-1 & TH-2 & TH-3 \\
\hline Asx & $1.0(1)$ & $1.0(1)$ & $3.0(3)$ & $3.1(2)$ \\
Glx & $-(0)$ & $1.2(1)$ & $1.4(1)$ & $-(0)$ \\
Ser & $1.0(1)$ & $-(0)$ & $2.7(3)$ & $2.5(3)$ \\
Thr & $-(0)$ & $-(0)$ & $-(0)$ & $-(0)$ \\
Pro & $0.9(1)$ & $-(0)$ & $1.8(2)$ & $1.8(2)$ \\
Gly & $1.1(1)$ & $-(0)$ & $5.0(4)$ & $4.0(4)$ \\
Ala & $0.9(1)$ & $0.9(1)$ & $1.2(1)$ & $-(0)$ \\
Val & $-(0)$ & $-(0)$ & $-(0)$ & $-(0)$ \\
Met & $-(0)$ & $-(0)$ & $-(0)$ & $-(0)$ \\
Leu & $1.0(1)$ & $0.8(1)$ & $2.5(3)$ & $1.2(2)$ \\
Ile & $-(0)$ & $-(0)$ & $0.9(1)$ & $0.8(1)$ \\
Tyr & $-(0)$ & $-(0)$ & $-(0)$ & $-(0)$ \\
Phe & $0.9(1)$ & $0.9(1)$ & $0.7(1)$ & $-(0)$ \\
His & $-(0)$ & $-(0)$ & $0.8(1)$ & $0.9(1)$ \\
Lys & $1.0(1)$ & $1.9(2)$ & $1.5(2)$ & $-(0)$ \\
Arg & $1.0(1)$ & $-(0)$ & $2.7(3)$ & $3.3(3)$ \\
Cys & $+(2)$ & $+(2)$ & $+(6)$ & $+(4)$ \\
\hline
\end{tabular}

Assignment

$$
\begin{aligned}
& \text { Phe }^{9}-\text { Arg }^{17} \text { Phe }^{9}-\text { Ala }^{12} \quad \text { Gly }^{1}-\text { Arg }^{8} \quad \text { Gly }^{1}-\text { Arg }^{8} \\
& \stackrel{+}{\text { Cys }^{24}-\text { Lys }^{25}} \underset{\text { Leu }^{22}-\mathrm{Glu}^{26}}{+} \mathrm{Phe}^{9}-\mathrm{Ala}^{12} \mathrm{Leu}^{13}-\mathrm{Gly}^{21} \\
& \mathrm{Leu}^{+13}-\mathrm{Glu}^{26} \mathrm{Ile}^{29}-\mathrm{Cys}^{34} \\
& \mathrm{Ile}^{29}-\mathrm{Cys}^{34}
\end{aligned}
$$

The theoretical numbers of residue are shown in parentheses. T-1, TH-1, TH-2 and TH-3 correspond to the peak fractions shown in Fig. 4.

cided with that of Syn-agel- $\mathrm{NH}_{2}\left(\mathrm{t}_{\mathrm{R}}=6.4 \mathrm{~min}\right)$ but not with Syn-agel-OH $\left(t_{R}=6.9 \mathrm{~min}\right)$ as shown in Fig. 3, confirming that the C-terminus of agelenin was amide form. Fig. 4 shows the chromatogram obtained from the tryptic and the thermolytic digests of agelenin. Each peak fraction was subjected to amino acid composition analysis and the fraction containing Cys was successively subjected to amino acid sequence analysis. Data concerning disulfide bonds are summarized in Table 1 and Fig. 5. T-1 and TH-1 indicated a disulfide bridge formation between $\mathrm{Cys}^{10}{ }^{10} \mathrm{Cys}^{24}$. TH-2 and TH-3 suggested two possible arrangements; i.e. $\mathrm{Cys}^{3}-\mathrm{Cys}^{18}$ and $\mathrm{Cys}^{19}-\mathrm{Cys}^{34}$, or $\mathrm{Cys}^{3}-\mathrm{Cys}^{19}$ and $\mathrm{Cys}^{18}{ }^{18} \mathrm{Cys}^{34}$.

\section{DISCUSSION}

In the present study, we determined the C-termi- 


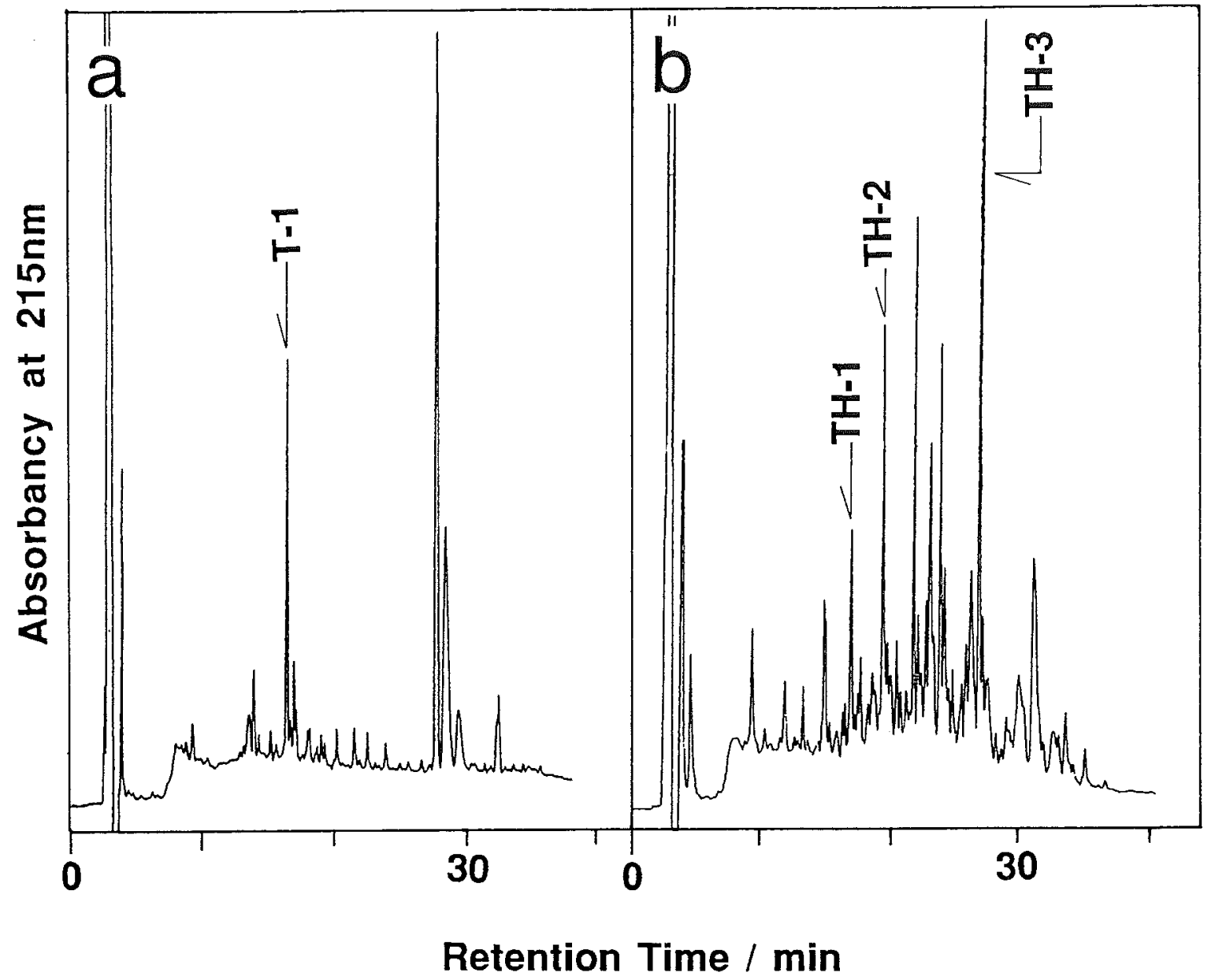

Fig. 4 Chromatograms of peptide fragments derived from digested agelenin. a, digestion by trypsin; b, digestion by thermolysin

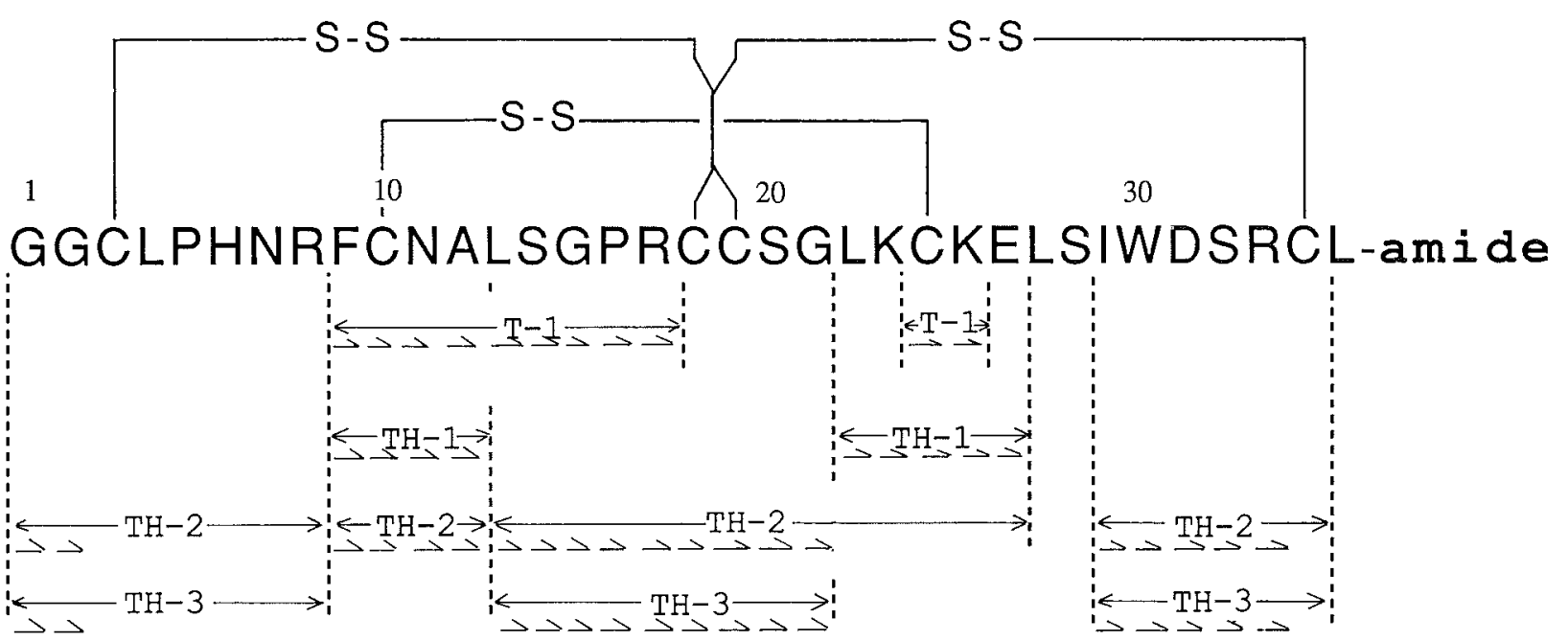

Fig. 5 Disulfide bonds arrangements in agelenin. $\rightarrow$, Identified as phenylthiohydantoin derivatives by the sequencer. A disulfide bond was defined between $\mathrm{Cys}^{10}$ and $\mathrm{Cys}^{24}$. Cys ${ }^{3}$ and $\mathrm{Cys}^{34}$ form disulfide bonds with $\mathrm{Cys}^{18}$ and $\mathrm{Cys}^{19}$ (the exact arrangement is unknown). 
nus of agelenin as Leu- $\mathrm{NH}_{2}$ by dansyl-Edman degradation analysis and also by authentic peptides synthesis. The C-terminal amide which often occurred in bioactive peptides is known to be posttranslational product during biosynthesis, via cleavage at-NH- $\mathrm{CH}_{2}$-bond of glycine in the precursor peptides which yields glyoxylic acid and the matured peptides of the C-terminal amide $(1,9)$. We suppose the biosynthesis of agelenin follows the similar processing route.

In Fig. 2a, DNS-Leu-OH was slightly detected, but we consider this to be an artifact generated during the dansyl-Edman process of peptide fragment. The elution profile of agelenin was entirely the same as that of Syn-agel- $\mathrm{NH}_{2}$, without any peak of Syn-agel-OH (Fig. 3). In dansyl-Edman analysis, it is noted that the dansylated sample was a mixture of DNS-Leu- $\mathrm{NH}_{2}{ }^{35}$ and DNS-CysSO ${ }_{3}^{-19}$-(Ne ${ }^{e}$-PTC) Lys- $\mathrm{OH}^{23}$ as indicated in Fig. 1. However, DNS$\mathrm{CySSO}_{3}^{-19}-\left(\mathrm{N}^{\varepsilon}\right.$-PTC)Lys-OH ${ }^{23}$ was not coeluted within the peak fraction of DNS-Leu- $\mathrm{NH}_{2}{ }^{35}$ (Fig. 2a). Acid hydrolysis and rechromatography of the peak fraction corresponding to DNS-Leu- $\mathrm{NH}_{2}{ }^{35}$ in Fig. 2a gave a peak corresponding to the authentic DNS-Leu-OH but not DNS-CysSO ${ }_{3}^{-}$(Fig. 2b).

In our previous paper (6), CP-P (EC 3.4.16.1) was used to determine the amino acid sequence in the C-terminal region of agelenin. Although the method using CP is widely used for the determination of the C-terminal amino acid sequence, it is not appropriate for the $\mathrm{C}$-terminal amide analysis, since CP releases amino acid amide at the $\mathrm{C}$-terminus (for example, $\mathrm{X}$-Leu- $\mathrm{NH}_{2}$ ) as either amide $(\mathrm{H}$ Leu- $\mathrm{NH}_{2}$ ) form or carboxylic acid (H-Leu-OH) form. Even though carboxylic acid form is exclusively detected by the $\mathrm{CP}$ analysis, there still remains the possibility that the $\mathrm{C}$-terminus is amide form.

Agelenin is known to have six Cys residues. Our preliminary study suggested that all Cy's residues formed disulfide bonds (data not published). In the present study, we determined that $\mathrm{Cys}^{10}$ was bonded to $\mathrm{Cys}^{24}$, judging from the tryptic and thermolytic peptide fragments of T-1 and TH-1. Assuming that $\mathrm{Cys}^{3}$ and $\mathrm{Cys}^{34}$ form a disulfide bond, Gly ${ }^{1}$ $\mathrm{Arg}^{8}$ and $\mathrm{Ile}^{29}$-Cys $^{34}$ should be bonded as one peptide by $\mathrm{Cys}^{3}-\mathrm{Cys}^{34}$. From the results of the amino acid composition and sequence analysis (Table 1 and Fig. 5), this assumed peptide is expected to be eluted in both fractions (TH-2 and TH-3) having different retention times; however, this is inconsistent with the general principle that one peptide has a unique retention time in HPLC. Thus, formation of a disulfide bond between $\mathrm{Cys}^{3}$ and $\mathrm{Cys}^{34}$ is unlikely. On the contrary, it is possible that the disulfide bond is formed as follows; $\mathrm{Cys}^{3}-\mathrm{Cys}^{18}$ and $\mathrm{Cys}^{19}{ }^{-\mathrm{Cys}^{34}}$, or $\mathrm{Cys}^{3}-\mathrm{Cys}^{19}$ and $\mathrm{Cys}^{18}{ }^{18} \mathrm{Cys}^{34}$. We could not define the precise arrangement because of a limited amount of agelenin available for analysis. However, in view of a recent report discussing all possible arrangements of three disulfide bridges in amino acid sequence (17), and of the characteristic of two adjoining Cys $\left(\mathrm{Cys}^{18}\right.$ and $\left.\mathrm{Cys}^{19}\right)$ in agelenin, agelenin seems to have a similar disulfide bond arrangement as $\omega$-conotoxin GVIA (5). Based on the cystine arrangement in $\omega$-conotoxin GVIA (10), the putative disulfide bond arrangement in agelenin is supposed to be $\mathrm{Cys}^{3}-\mathrm{Cys}^{19}$, $\mathrm{Cys}^{10}{ }^{1} \mathrm{Cys}^{24}$ and $\mathrm{Cys}^{18}{ }^{18} \mathrm{Cys}^{34}$. Although several Cysrich toxins have been purified from spider venom $(2,4,11-14)$, the investigation of disulfide bonds was reported only for $\mu$-agatoxin (13). $\mu$-Agatoxin was reported to have four disulfide bonds (i.e. eight Cys residues) in the molecule and the arrangement of two bonds have been determined. However, the other two bonds have not been defined yet, remaining two possible arrangements.

Synthesis of agelenin (Syn-agel- $\mathrm{NH}_{2}$ ) used in the present study will be reported elsewhere.

Received 22 July 1991; and accepted 29 August 1991

\section{REFERENCES}

1. Bradbury A. F. and Smyth D. G. (1987) Enzyme-catalysed peptide amidation. Eur: J. Biochem. 169, 579-584

2. Brown M. R., Sheumack D. D., Tyler M. I. and Howden M. E. H. (1988) Amino acid sequence of versutoxin, a lethal neurotoxin from the venom of the funnel-web spider Atrax versutus. Biochem. J. 250, 401-405

3. Cunico R. L. and Schlabach T. (1983) Comparison of ninhydrin and $o$-phthalaldehyde post-column detection techniques for high-performance liquid chromatography of free amino acids. J. Chromatogr. 266, 461-470

4. Diniz C. R., Cordeiro M. N., Junor L. R., Kelly P., FisCher S., Reimann F, Oliveira E. B. and Richardson M. (1990) The purification and amino acid sequence of the lethal neurotoxin Txl from the venom of the Brazilian 'armed' spider Phoneutria nigriventer. FEBS Lett. 2, 251-253

5. Gray W. R., Olivera B. M. and Cruz L. J. (1988) Peptide toxins from venomous Comus snails. Ann. Rev. Biochem. 57, 665-700

6. Hagiwara K., Sakai T., Miwa A., Kawai N and Nakajima T. (1990) Complete amino acid sequence of a new type of neurotoxin from the venom of the spider, Agelena opulenta. Biomedical Res. 11, 181-186

7. JACKSON H. and PARKS T. N. (1989) Spider toxins: Recent applications in neurobiology. Ann. Rev. Neurosci. 12, 405- 
414

8. Kawai N., Miwa A., Shimazaki K., Sahara Y., Robinson H. P. C. and Nakajima T. (1991) Spider toxin and the glutamate receptors. Comp. Biochem. Physiol. 98C, 87-95

9. KreIL G. (1984) Occurrence, detection, and biosynthesis of carboxy-terminal amides. Meth. Enzymol. 106, 218-223

10. Nishiuchi Y., Kumagaye K., Noda Y., Watanabe T. X. and SAKAKIBARA S. (1986) Synthesis and secondary-structure determination of $\omega$-conotoxin GVIA: A 27-peptide with three intramolecular disulfide bonds. Biopolymers 25, S61-S68

11. Savel-Niemann A. (1989) Tarantula (Eurypelma californicum) venom, a multicomponent system. Biol. Chem. Hoppe-Seyler 370, 485-498

12. Sheumack D. C., Claassens R., Whiteley N. M. and Howden M. E. H. (1985) Complete amino acid sequence of a new type of lethal neurotoxin from the venom of the funnel-web spider Atrax robustus. FEBS Lett. 181, 154-
156

13. Skinner W. S., Adams M. E., Quistad G. B., Kataoka H., Cesarin B. J., Enderlin F. E. and Schooley D. A. (1989) Purification and characterization of two classes of neurotoxins from the funnel web spider, Agelenopsis aperta. $J$. Biot. Chem. 264, 2150-2155

14. Stapleton A., Blankenship D. T., Ackermann B. L., Chen T.-M., Gorder G. W., Manley G. D., Palfreyman M. G., Coutant J. E. and Cardin A. D. (1990) Curtatoxins. J. Biol. Chem. 265, 2054-2059

15. TARR G. E. (1977) Improved manual sequencing methods. Meth. Enzymol. 47, 335-357

16. Toennies G. and Homiller R. P. (1942) The oxidation of amino acids by hydrogen peroxide in formic acid. J. Amer: Chem. Soc. 64, 3054-3056

17. WARnE N. W. and LASKowSKi M. (1990) All fifteen possible arrangements of three disulfide bridges in proteins are known. Biochem. Biophys. Res. Commun. 172, 1364-1370 